\title{
Marine peptides act as novel chemotherapeutic agent
}

\begin{abstract}
The marine environment represents a largely unexplored source of new microbes (bacteria, fungi, microalgae-cyanobacteria) that are potent producers of bioactive peptides. Here, we have discussed some novel peptides isolated from marine species exhibiting antibacterial, antifungal, antiviral, antiprotozoal activities. Therefore, marine peptides have attracted a great deal of attention due to their potential effects in promoting health and reducing disease. We have also discussed the extraction and commercial exploitation of peptides to become a possible future drug. Advancements in isolated techniques have allowed us easy access of less explored environment. Here, we summarize the future aim and scope of commercial application and production of microbial peptides from marine sources.
\end{abstract}

Keywords: microalgae, cyanobacteria antiviral, antiprotozoal, antitumour
Volume 6 Issue 6 - 2018

\author{
Akanksha Srivastava, ' Vaibhav Mishra ${ }^{2}$ \\ 'Division of Microbiology, CSIR-Central Drug Research Institute, \\ India \\ ${ }^{2}$ Department of Environmental Microbiology, Babasaheb \\ Bhimrao Ambedkar University, India
}

Correspondence: Dr.Vaibhav Mishra,Assistant Professor, Industrial Microbiology (Innovative Course), Department of Environmental Microbiology, Babasaheb Bhimrao Ambedkar University, Lucknow-226025, U.P. India, Tel +9l-94503327/ 0, Emailvm.bbau@gmail.com

Received: March 01, 2017 | Published: December 27, 2018

\section{Introduction}

Emergence of drug-resistant pathogens and infectious diseases caused by bacteria, fungi and viruses increases the demand of developing novel and effective antibiotics. For the discovery of new antibiotics terrestrial environment was centralized for more than 50 years, and marine sources have remained unexplored for production of new anti-infectious metabolites. Now-these-days research has been focused on ocean as it occupies almost $70 \%$ of earth's surface and it provides a unique source of chemical compounds with potential bioactivities. ${ }^{1}$ In the last few decades, marine sources have played a major role for exploring and developing new drugs. ${ }^{2}$ But still many bioactive metabolites have to be explored, because of the difficulties in cultivation of deep water habitats. The marine habitat represents a new source of microbes including bacteria, fungi, microalgaecyanobacteria) that can be effective producers of bioactive metabolites. $^{3}$

Many marine species (like; bacteria, fungus, algae, fish and crab) secrets peptides so extensive research has been conducted on them. Bioactive marine peptides are effective due to their structural properties like amino acid composition and sequences with varying degrees of action. Marine peptides are currently used as antibiotics against infectious diseases such as human immunodeficiency virus (HIV) and conditions of multiple bacterial infections, antitumour, anticancer, antimicrotubule, antiproliferative and in cytotoxic activities. ${ }^{4-7}$ Therefore, marine peptides have attracted a great deal of attention due to their potential effects in promoting health and reducing disease. In this mini-review, we discuss the marine peptides isolation and extraction from varying sources, also their activity against bacterial, fungal, protozoan and viral infections with current status of peptides at commercial level.

\section{Marine microorganisms are major sources of microbial peptides}

Marine microbial species survive in a stressful habitat, under cold, lightless, and high-pressure conditions. These factors involved in development of unique metabolisms, and result in the production of novel metabolites that differ from terrestrial organisms. Thus, marine microbes offer a magnificent source for the discovery of new compounds with different activities, including antimicrobial, antiprotozoan, anti-tuberculosis, and antiviral properties. ${ }^{8,9}$

Peptides from marine bacteria: A large volume of unknown marine microbes are present in environment and to be a very good source of novel molecules crack many unsolved queries. Bacteria are the best source for production of microbial peptides. They are able to produce many bioactive molecules in the marine, principally to keep away their predators and protecting themselves. Furthermore, marine bacteria produces novel microbial peptides that showing antitumour, anticoagulant and cardio protective properties. ${ }^{10}$ According to literatures some of the unique properties of bacterial peptides, like their ability to grow and functionally active at extremely elevated salt concentrations, make them good potential targets for development of new and novel molecules against various diseases.

Peptides from marine fungi: All forms of life are present in the oceanic environment especially, fungi play a key role to isolate and produce marine peptides. There are two types of marine fungi obligate and facultative. ${ }^{11}$ Obligate fungi are grown completely in a marine or estuarine habitat whereas facultative fungi are grown and sporulate in terrestrial or freshwater. ${ }^{12}$ Marine fungi have proven to be a rich and promising source of novel therapeutics agents. Near about 272 microbial peptides have been isolated from marine fungi and the number is still increasing. ${ }^{13}$ In addition, most of these microbial peptides are analogues of those discovered previously from terrestrial fungi. ${ }^{14}$

Peptides from marine sponges: Marine sponges (phylum Porifera) are one of the richest sources of pharmacologically-active chemicals. They are sessile marine feeders that have developed efficient defense mechanisms against foreign attackers such as viruses, bacteria, or eukaryotic organisms. It has been suggested that many of the bioactive metabolites isolated from sponges and their associated microorganisms are produced by functional enzyme clusters. ${ }^{15,16}$ The huge number of different secondary metabolites discovered in marine sponges and the complexity of the compounds and their biosynthetic pathways can be regarded as their importance for survival. As infectious microbes evolve and develop resistance to existing pharmaceuticals, marine sponges provide novel leads against bacterial, fungal and viral diseases. 
Peptides from marine algae: Algae are very simple chlorophyllcontaining organisms composed of one cell or grouped together in colonies or as organisms with many cells, sometimes collaborating together as simple tissues. ${ }^{17}$ Algae are heterogeneous group of plants with a long fossil history. Blue-green algae (cyanobacteria) contain chlorophyll a and related compounds. These algae are ancient photosynthetic prokaryotic organisms that producing biologically active metabolites with diverse chemical structures such as nitrogenous compounds and cyclic polyethers. ${ }^{18}$ Recently, several marine cyanobacterial have been the focused due to their effective biological activities and unique structures.

Table I Marine peptides from diverse sources with anti-infective activities ${ }^{19}$

\begin{tabular}{|c|c|c|c|}
\hline Source & Name of Peptide & Activity & Pharmacologic Activity \\
\hline Bacterium: Brevibacillus laterosporus & Tauramamide (3) & Antibacterial & Enterococcus sp. inhibition \\
\hline Bacterium: Streptomyces sp. & Anthracimycin (35) & Antibacterial & $\begin{array}{l}\text { B. anthracis, Enterococcus facecalis, Streptococcus } \\
\text { pneumonia, S. aureus, MSSA, MRSA, vanco-mycin- } \\
\text { resistant } S . \text { aureus inhibition }\end{array}$ \\
\hline Bacterium: Rapidithrix sp. & Ariakemicins A (25), B (26) & Antibacterial & Brevibacterium sp., S. aureus, B. subtilis \\
\hline Bacterium: Bacillus silvestris & Bacillistatins 1 (7), 2 (8) & Antibacterial & Streptococcus. pneumonia inhibition \\
\hline Bacterium: Nocardiopsis sp & Nacardiopsis thiopeptide TP-1161 (9) & Antibacterial & Vancomycin-resistant Enterococcus faecium inhibition \\
\hline Bacterium: Phaeobacter sp & Indigoidine (15) & Antibacterial & Vibrio fischeri inhibition \\
\hline Bacterium: Photobacterium sp. & Unnarmicins A (16), C (17) & Antibacterial & Pseudovibrio sp. inhibition \\
\hline Bacterium: Photobacterium sp. & Ngercheumi-cins A-D (18-21) & Antibacterial & Gram negative strain inhibition \\
\hline Bacterium: Photobacterium sp. & Solonamidine A (22), B (23) & Antibacterial & S. aureus, Methicillin-resistant S. aureus (MRSA) \\
\hline Bacterium: Pseudomonas sp. & Cyclo-peptides (24) & Antibacterial & $\begin{array}{l}\text { S. aureus, M. luteus, B. subtilis, E. coli, } V . \\
\text { anguillarum }\end{array}$ \\
\hline Fungus: Leucostoma persoonii & Cytosporones B (33), E (34) & Antibacterial & S. aureus USA100, MRSA, MSSA inhibition \\
\hline Fish: Oreochromis mossambicus & Hepcidin (4) & Antibacterial & $\begin{array}{l}\text { Listeria monocytogenes, } S . \text { aureus, and Enterococcus } \\
\text { faecium inhibition }\end{array}$ \\
\hline Jellyfish: Aurelia aurita & Aurelin (1) & Antibacterial & Escheichia coli inhibition \\
\hline $\begin{array}{l}\text { Bacterium: Chondromyces } \\
\text { Pediculatus }\end{array}$ & Pedein A (39) & Antifungal & $\begin{array}{l}\text { Rhizopus glutinis, Saccharomyces cerevisae, } C \text {. } \\
\text { albicans inhibition }\end{array}$ \\
\hline Sponge: Latrunculia sp. & Callipeltine J(37), K (38) & Antifungal & C. albicans \\
\hline Sponge: Theonella sp. & Theuellamide F (40), G (41) & Antifungal & C. albicans inhibition \\
\hline Bacterium: Lyngbya majuscula & Dragomabin (54) & Antimalarial & Plasmodium falciparum W2 strain inhibition \\
\hline Bacterium: Oscillatoria sp. & Venturamid A (55), B (56) & Antimalarial & Plasmodium falciparum W2 \\
\hline Bacteriun: Microcystis aeruginosa & Aerucyamide A-D (57-60) & Antimalarial & Plasmodium falciparum $\mathrm{K} 1$ \\
\hline Bacterium: Schizothrix sp. & Gallinamide A (61 & Antimalarial & Plasmodium falciparum $\mathrm{W} 2$ \\
\hline Bacterium: Lyngbya majuscula & Lagunamide A (62), B (63) & Antimalarial & Plasmodium falciparum NF54 strain inhibition \\
\hline Bacterium: Oscillatoria nigro-viridis & Viridamide A (65), B (66) & Antiprotozoal & Leishmania mexicana, Trypanosoma cruzi inhibition \\
\hline Bacterium: Lyngbya majuscula & Almiramides B (67), C (68) & Antiprotozoal & Leishmania donovani inhibition \\
\hline Bacterium: Streptomyces sp. & Valinomycin (69) & Antiprotozoal & Leishmania major \& Trypanosoma brucei inhibition \\
\hline Fungus: A. fumigatus, Nectria inventa & Diketopiperazines (70-81) & Antiprotozoal & Trypanosoma brucei \\
\hline Fungus: Trichoderma sp. & Trichoderin A (82), A1 (83), B (84) & Antitubercu-losis & Mycobacterium tuberculosis \\
\hline Fungus: Aspergillus terreus & Asperterrestide A (98) & Antiviral & Anti-HIN1, Anti-H3N2 \\
\hline Sponge: Siliquariaspongiamirabilis & Celebesides A (94), C (95) & Antiviral & Anti-HIV-1 \\
\hline Sponge: Theonella swinhoei & Theopapu-amide A (96), D (97) & Antiviral & Anti-HIV-1 \\
\hline Sponge:Siliquariaspongia mirabilis & $\begin{array}{l}\text { Mirabamides A (85), C (86), D (87), } \\
\text { E-H (88-91) }\end{array}$ & Antiviral & Anti-HIV-1 \\
\hline Sponge: Homophymia sp. & $\begin{array}{l}\text { Homophymine A-E (99-103), } \\
\text { A1-E1 (104-108) }\end{array}$ & Antiviral & Anti-HIV-1 \\
\hline Sponge: Theonella sp. & Koshikmaide B (109), F-H (110-112) & Antiviral & Anti-HIV-1 \\
\hline
\end{tabular}

Peptides from marine invertebrate: Apart from microbes some invertebrates are also produces peptides and these peptides have some unique properties especially peptides from fishes are using as novel chemotherapeutics agents against microbes. Fish peptides are showing broad-spectrum antimicrobial activity against both fish and human pathogens. These peptides encoding genes are highly responsive to microbes and innate immunostimulatory molecules. Recent research has reported some unique properties of fish peptides, including their ability to act even at very high salt concentrations, make them good potential targets for development as therapeutic antimicrobials. ${ }^{5}$ Some marine peptides from these different sources with their antagonist activity are discussed in Table 1 . 


\section{Isolation of marine peptides from microbes}

To isolate the peptides from sea water sample at different depth is collected from ocean. A variety of pre-treatment methods including enrichment, physical, and chemical techniques (e.g., dry heat, exposure to $1 \%-1.5 \%$ phenol, sucrose-gradient centrifugation, and filtration through cellulose membrane filters) are employed to favor the isolation of specific genera and improve the recovery of marine peptides. ${ }^{20}$ These pre-treatment's eliminate or strongly reduce the risk of contamination, thereby facilitating the isolation of marine peptides.

\section{Extraction of marine peptides for commercial applications}

Bioactive peptides or protein hydrolysates from marine species can be extracted and isolated by various methods in industrialscale production. The organic solvent extraction method was used traditionally, but due to its time-consumption and costlier, some improved extraction techniques like pressurized solvent, supercritical fluid, pulsed electric field-assisted, microwave-assisted, ultrasoundassisted and enzyme-assisted are preferred. ${ }^{21}$

After the extraction procedure, the proteins are hydrolyzed into bioactive peptides. Enzymatic hydrolysis is preferred in the nutraceutical and pharmaceutical industries in order to avoid harsh chemical and physical treatment and preserve the functionality and nutritive values. ${ }^{22} \mathrm{~A}$ novel ultra filtration membrane bioreactor technology has recently emerged. Nowadays, marine peptide are obtained by multistep recycling membrane reactor combined with an ultra filtration membrane system to fractionate marine hydrolysates according to different molecular weight ranges. ${ }^{23}$ Some of marine peptides obtained from these sources are in clinical trials which have been elaborated in Table 2 .

Table 2 Marine peptides in clinical trials ${ }^{24}$

\begin{tabular}{|c|c|c|c|}
\hline Source & Compound & Applications & Status \\
\hline$\omega$-conotoxin toxin from Conus magus & Ziconotide & Analgesics & FDA approved \\
\hline Dolabella auricularia & Brentuximab vedotin & Cancer treatment & FDA approved \\
\hline Dolabella auricularia & Glembatumumab vedotin & Cancer treatment & Phase I/II clinical study \\
\hline pentapeptide from hydrolysate of dried bonito & Katsuobushi & Antihypertensive & Sold as nutraceuticals \\
\hline oligopeptide extract from Chlorella vulgaris & Dermochlorella ${ }^{\circledR}$ & Skin toner and firmer & Sold as skin care product \\
\hline Aplidium albicans & Plitidepsin & Cancer treatment & Phase I/II clinical study \\
\hline Hemiasterella minor & HTI-286 & Cancer treatment & Preclinical study \\
\hline Elysia rufescens & Kahalalide F & Cancer treatment & Phase I clinical study \\
\hline Elysia rufescens & Elisidepsin & Cancer treatment & Phase I clinical study \\
\hline Hydrolysate of fish collagen and gelatin & Fish gelatin & Supplements and bone health & Sold as nutraceuticals \\
\hline Hydrolysate of fish protein & Stabilium Protizen/Procalm & Anxiolytic & Sold as nutraceuticals \\
\hline Hydrolysate of fish protein & Seacure & Intestinal health & Sold as nutraceuticals \\
\hline Hydrolysate of fish protein & $\begin{array}{l}\text { Nutripeptin } ₫ / \text { Hydro MN } \\
\text { Peptide } \AA\end{array}$ & $\begin{array}{l}\text { Postprandial blood glucose } \\
\text { control }\end{array}$ & Sold as nutraceuticals \\
\hline
\end{tabular}

\section{Conclusion}

The discovery of bio regulatory roles with elucidation of the marine peptides mechanisms would promote the peptides to be used as potential drugs for treatment of diseases. With the advancement of marine peptides to the current preclinical and clinical stages, their contribution in the future shows some potential. New technologies and close collaborations between institutional and industrial investigators will be crucial to ensure the future success of marine peptides as novel therapeutics that can make a vital contribution to the treatment or prevention of various diseases.

\section{Acknowledgments}

The authors would like to thank the Council of Scientific and Industrial Research (CSIR), India and Babasaheb Bhimrao Ambedkar University to provide all the necessary facility for research.

\section{Conflicts of interest}

No conflict of interest declared.

\section{References}

1. Abad MJ, Bedoya LM, Bermejo P. Marine compounds and their antimicrobial activities. Science against microbial pathogens: communicating current research and technological advances A. MendezVilas (Ed.); 2011. 1293-1306 p.

2. Xiong ZQ, Wang JF, Hao YY, et al. Recent Advances in the Discovery and Development of Marine Microbial Nat Products. Mar Drugs. 2013;11(3):700-717

3. Aneiros A, Garateix A. Bioactive peptides from marine sources: Pharmacological properties and isolation procedures. $J$ Chromatogr B Analyt Technol Biomed Life Sci. 2004;803(1):41-53.

4. Mayer AM, Rodriguez AD, Berlinck RG, et al. Marine pharmacology in 2009-2013: Marine compounds with antibacterial, antidiabetic, antifungal, anti -inflammatory, antiprotozoal, antituberculosis and antiviral activities; affecting the immune and nervous systems, and other miscellaneous mechanisms of action. Mar Drugs. 2013;11:2510-2573.

5. Masso SJA, Diamond G. Antimicrobial Peptides from Fish. Pharmaceuticals. 2014;7(3):265-310. 
6. Kim SK, Wijesekara I. Development and biological activities of marinederived bioactive peptides: A review. Journal of Functional Foods. 2010;2(1):1-9.

7. Ngo DH, Vo TS, Ngo DN, et al. Biological activities and potential health benefits of bioactive peptides derived from marine organisms. Int $J$ Biol Macromol. 2012;51(4):378-383.

8. Lu X, Gao X, Liu X, et al. Marine microbes-derived anti-bacterial agents. Mini Rev Med Chem. 2010;10(11):1077-1090.

9. Rahman H, Austin B, Mitchell WJ, et al. Novel anti-infective compounds from marine bacteria. Mar Drugs. 2010;8(3):498-518.

10. Austin B. A review novel on pharmaceutical compounds from marine bacteria. J Appl Bacteriol. 1989;67:461-470.

11. Holler U. Isolation, biological activity and secondary metabolite investigations of marine derived fungi and selected host sponges. $\mathrm{PhD}$ Thesis, Universitat Carolo, USA: Wilhelmina; 1999. 163 p.

12. Kohlmeyer J. Bremerhaven: Veroff Inst Meeresforsch. 1974;Suppl 5:263-286.

13. Bugni TS, Ireland CM. Marine derived fungi: a chemically and biologically diverse group of microorganisms. Nat Prod Rep. 2004;21(1):143-163.

14. Davidson BS. New dimensions in natural products research: cultured marine microorganisms. Curr Opin Biotechnol. 1995;6(3):284-291.
15. Laport MS, Santos DC, Muricy G. Marine sponges: Potential sources of new antimicrobial drugs. Curr Pharm Biotechnol. 2009;10(1):86-105.

16. Sagar S, Kaur M, Minneman KP. Antiviral lead compounds from marine sponges. Mar Drugs. 2010;8(10):2619-2638.

17. Cardozo KHM, Guaratini T, Barros MP, et al. Metabolites from algae with economical impact. Comp Biochem Physiol C. 2007;146(1-2):60 78.

18. Tan LT. Bioactive natural products from marine cyanobacteria for drug discovery. Phytochemistry. 2007;68(7):954-979.

19. Kang HK, Chang HS, Yoonkyung P. Marine Peptides and Their AntiInfective Activities. Mar Drugs. 2015;13(1):618-654.

20. Esin E, Hames KAU. Isolation strategies of marine-derived actinomycetes from sponge and sediment samples. J Microbiol Methods. 2012;88(3):342-347.

21. Grosso C, Valentao P, Ferreres F, et al. Alternative and efficient extraction methods for marine-derived compounds. Mar Drugs. 2015;13(5):31823230 .

22. Clemente A. Enzymatic protein hydrolysates in human nutrition. Trends Food Sci Technol. 2000;11(7):254-262.

23. Zhao Y, Li B, Dong S, et al. Novel ACE inhibitory peptide isolated from Acaudina molpadioidea hydrolysate. Peptides. 2009;30(6):1028-1033.

24. Randy CF, Tzi BN, Jack HW. Marine Peptides: Bioactivities and Applications. Mar Drugs. 2015;13(7):4006-4043. 